\title{
Two Phases in the Evolution of the Body Size of Dinosaurs
}

\author{
Jerzy Trammer \\ Institute of Geology, Warsaw University, Al. Żwirki i Wigury 93, 02-089 Warszawa, Poland \\ E-mail: jtrammer@uw.edu.pl
}

Received: July 26, 2011 Accepted: August 18, $2011 \quad$ Published: March 1, 2012

doi:10.5539/jgg.v4n1p75 URL: http://dx.doi.org/10.5539/jgg.v4n1p75

\begin{abstract}
During the Late Triassic - Jurassic phase of the evolution of dinosaurs, their mean and maximum body size increased concurrently with increasing species diversity. On the contrary, in the Cretaceous, although the number of dinosaur species increased, the body size ultimately decreased. This might have been connected with the increase of the number of land masses and the decrease of their areas in the Late Cretaceous caused by global tectonics.
\end{abstract}

Keywords: Dinosauria, Species diversity, Body size, Evolution, Global tectonics

\section{Introduction}

The aim of the present contribution was to recognize how the evolutionary changes of body size of dinosaurs were related to the changes of their species diversity. As yet this question was not investigated respecting the Dinosauria.

\section{Material and Methods}

Dinosaurs appeared in the Late Triassic Carnian Age and disappeared 164.5 million years later at the end of the Cretaceous in the Maastrichtian. I have divided this time span into 14 intervals (Table 1) of similar length. Using data from the most complete compendium of the dinosaur body masses (Paul, 2010), I computed the number of the found dinosaur species, as well as the mean and maximum body mass of those species for each interval. I have taken into consideration all the species from Paul (2010) with a known age of occurrence and estimated mass.

Different methods resulting in disparate estimates are employed to obtain body masses of dinosaur species. There is advantageous, therefore, that all the mass estimates of Paul (2010) are based on the same method: on the measure of a dinosaur volume - then converted into body mass (for the explanation of the method see Paul 1997).

There is no correlation between the number of species and the duration of an interval ( $r=-0.033 ; \mathrm{p}$ (uncorrelated) $=0.91$ ). Results of the calculations (Table 1) are plotted in the form of time series (Figure 1).

\section{Results}

Two distinct phases (Figure 1) may be distinguished during the evolutionary history of dinosaurs: the first - from their appearance in the Triassic till the end of the Jurassic Period (intervals 1 to 7), and the second one - in the Cretaceous (intervals 8 to 14 ).

In the first phase, both the time series of the species number and those for the mean and maximum body mass contain statistically significant upward trends (regression coefficients $\mathrm{r}$ of the series values against their observation times amount $0.834, p=0.019 ; 0.855, p=0.014$ and $0.785, p=0.036$, respectively). Throughout this phase the mean and maximum body mass are strongly correlated with the species diversity (for first differences $r$ $=0.97, p=0.0002$ and $r=0.967, p=0.00035$, respectively). This suggests that increase in body mass was driven by increasing species diversity.

During the second (Cretaceous) phase, after the extinction in the latest Jurassic, the number of species increased again showing an upward trend $(\mathrm{r}=0.827, \mathrm{p}=0.021)$. The species increase was even almost twice as fast as in the first phase (Figure 1). However, the mean and the maximum body mass provide no statistically significant trends $(\mathrm{r}=0.176, \mathrm{p}=0.705$ and $\mathrm{r}=0.68, \mathrm{p}=0.09$, respectively), and there is no significant correlation between the mean and the maximum body mass and the specific diversity (first differences $r=-0.72, p=0.104$ and $r=-$ 
$0.409, \mathrm{p}=0.419$, respectively). Contrary to the first phase, in the second phase the dinosaurs were not consistently larger with increasing diversity.

\section{Discussion}

It is likely that the pattern presented in Figure 1 is at least partly caused by global tectonics. There were four continents in the Late Jurassic but already nine in the Late Cretaceous and the mean area of a continent decreased almost three times at that time in comparison with the Late Jurassic continents (Smith et al., 1994; Figure 1). This might have increased the species number of dinosaurs by increasing their provinciality (Kurten, 1969; Schopf, 1979; Dodson, 1990; Rosenzweig, 1995; Hedges et al., 1996) but simultaneously decreased their maximum and mean body mass, as the body size of big animals decreases with decreasing land area (Burness et al., 2001).

Many authors argued that in a radiating clade there is a strong correlative relation between the maximum body size and species diversity (Stanley, 1973; Gould, 1988; McShea, 1994; Trammer \& Kaim, 1997; Trammer, 2002, 2005; Gillman, 2007; McClain \& Boyer, 2009) such that the continuing increase in size parallels diversification. Other researches (Smith et al. 2010) did not provide support for such strong correlation. The example of dinosaurs presented herein suggests that under conditions of unconstrained diversification, the maximum body size changes with time in concert with the diversity but the size of a land area may ultimately constrain the increase of body size weakening the correlation between size and diversity.

As it is widely acknowledged, differentiated sampling intensity of various parts of the geological column may bias the results of quantitative studies based on the fossil record (e.g. Smith, 2007). The number of formations may be used as an estimate of sampling intensity related to rock availability, paleontologist interest etc. (Peters \& Foote, 2001; Wang \& Dodson, 2006). The number of terrestrial formations in each of the Early, Middle and Late Jurassic epochs is significantly smaller than in the Late Triassic Epoch (Peters \& Foote 2001, Wang \& Dodson 2006), therefore the Late Triassic - Late Jurassic increase in the species number (Figure 1) is likely to be genuine and not an artifact of sampling intensity. The number of terrestrial formations in the Late Cretaceous is greater than in the Early Cretaceous (Peters \& Foote 2001, Wang \& Dodson 2006)), so the Cretaceous increase in the species number (Figure 1) may be spurious but the study of Wang \& Dodson (2006) showed that this increase was rather genuine. The maximum size, sampled from the statistical population of differently sized objects, increases with sample size. On the contrary, the maximum size of dinosaurs decreased with the increasing number of formations and the increasing number of species in the Late Cretaceous, which suggests that this decrease may be reliable.

\section{References}

Burness, G. P., Diamond, J. \& Flannery, T. (2001). Dinosaurs, dragons, and dwarfs: the evolution of maximal body size. PNAS, 98, 14518-14523. http://dx.doi.org/10.1073/pnas.251548698

Dodson, P. (1990). Counting dinosaurs: how many kinds were there? Proc. Natl. Acad. Sci. USA, 87, 7608-7612. http://dx.doi.org/10.1073/pnas.87.19.7608

Gillman, M. P. (2007). Evolutionary dynamics of vertebrate body mass range. Evolution, 61, 685-693. http://dx.doi.org/10.1111/j.1558-5646.2007.00060.x

Gould, S. J. (1988). Trends as change in variance: a new slant on progress and directionality in evolution. Journal of Paleontology, 62, 319-329.

Hedges, S. B., Parker, P. H., \& Sibley, Ch. G. (1996). Continental breakup and the ordinal diversification of birds and mammals. Nature, 381, 226-229. http://dx.doi.org/10.1038/381226a0

Kurten, B. (1969). Continental drift and evolution. Scientific American, 220, 54-64. http://dx.doi.org/10.1038/scientificamerican0369-54

McClain, C. R. \& Boyer, A. G. (2009). Biodiversity and body size are linked across metazoans. Proceedings of the Royal Society B, 276, 2209-2215. http://dx.doi.org/10.1098/rspb.2009.0245

McShea, D. W. (1994). Mechanism of large-scale evolutionary trends. Evolution, 48, 1747-1763. http://dx.doi.org/10.2307/2410505

Paul, G. (1997). Dinosaurs models: the good, the bad, and using them to estimate the mass of dinosaurs. In D. L. Wolberg, E. Stump \& G. Rosenberg (Eds.). Dinofest International: Proceedings of a symposium sponsored by Arizona State University (pp. 129-142). Philadelphia: Academy of Natural Sciences.

Paul, G. (2010). The Princeton field guide to dinosaurs. Princeton and Oxford: Princeton University Press. 
Peters, S. E. \& Foote, M. (2001). Biodiversity in the Phanerozoic: a reinterpretation. Paleobiology, 27, 583-601. http://dx.doi.org/10.1666/0094-8373(2001)027<0583:BITPAR >2.0.CO;2

Rosenzweig, M. L. (1995). Species diversity in space and time. Cambridge: Cambridge University Press. http://dx.doi.org/10.1017/CBO9780511623387

Schopf, T. J. M. (1979). The role of biogeographic provinces in regulating marine faunal diversity through geologic time. In J. Gray, \& A. J. Boucot (Eds.). Historical biogeography, plate tectonics, and the changing environment (pp. 449-457). Corvallis: Oregon State University Press.

Smith, A. B. (2007). Marine diversity through the Phanerozoic: problems and prospects. Journal of the Geological Society London, 164, 731-745. http://dx.doi.org/10.1144/0016/76492006-184

Smith, A. G., Smith, D. G. \& Funnell, B. M. (1994). Atlas of Mesozoic and Cenozoic coastlines. Cambridge: Cambridge University Press.

Smith, F. A., Boyer, A. G., Brown, J. H., et al. (2010). The evolution of maximum body size of terrestrial mammals. Science, 330, 1216-1219. http://dx.doi.org/10.1126/science.1194830

Stanley, S. M. (1973). An explanation for Cope's rule. Evolution, 27, 1-25. http://dx.doi.org/10.2307/2407115

Trammer, J. (2002). Power formula for Cope's rule. Evolutionary Ecology Research, 4, 147-153.

Trammer, J. (2005). Maximum body size in a radiating clade as a function of time. Evolution, 59, 941-947.

Trammer, J. \& Kaim, A. (1997). Body size and diversity exemplified by three trilobite clades. Acta Palaeontologica Polonica, 42, 1-12.

Wang, S. C. \& Dodson, P. (2006). Estimating the diversity of dinosaurs. PNAS, 103, 13601-13605. http://dx.doi.org/10.1073/pnas.0606028103

Table 1. Species-level diversity and body size of dinosaurs in fourteen intervals of their evolutionary history. Computed using data from Paul (2010)

\begin{tabular}{|l|l|c|c|c|c|}
\hline \multirow{2}{*}{$\begin{array}{c}\text { Number } \\
\text { of interval }\end{array}$} & \multicolumn{1}{|c|}{ Included stages } & \multirow{2}{*}{$\begin{array}{c}\text { Duration } \\
\text { of interval [Ma] }\end{array}$} & $\begin{array}{c}\text { Number } \\
\text { of species }\end{array}$ & \multicolumn{2}{|c|}{ Body mass [kg] } \\
\hline 14 & Maastrichtian & 5.5 & 83 & 3,392 & 50,000 \\
\hline 13 & Turonian, Campanian & 15 & 144 & 2,104 & 50,000 \\
\hline 12 & Cenomanian, Turonian, Coniacian & 14 & 53 & 6,659 & 80,000 \\
\hline 11 & Albian & 12 & 42 & 5,471 & 50,000 \\
\hline 10 & Aptian & 13 & 42 & 2,624 & 20,000 \\
\hline 9 & Hauterivian, Barremian & 9 & 35 & 3,689 & 35,000 \\
\hline 8 & Berrasian, Valanginian & 11 & 10 & 2,212 & 17,000 \\
\hline 7 & Kimmeridgian, Tithonian & 11 & 78 & 9,567 & 125,000 \\
\hline 6 & Callovian, Oxfordian & 9 & 47 & 5,363 & 75,000 \\
\hline 5 & Aalenian, Bajocian, Bathonian & 11 & 27 & 3,470 & 14,000 \\
\hline 4 & Pliensbachian, Taorcian, & 14 & 19 & 604 & 3,500 \\
\hline 3 & Rhaetian, Hetaangian, Sinemurian & 14 & 27 & 1,202 & 7,000 \\
\hline 2 & Norian & 13 & 20 & 952 & 7,000 \\
\hline 1 & Carnian & 13 & 9 & 83 & 500 \\
\hline
\end{tabular}




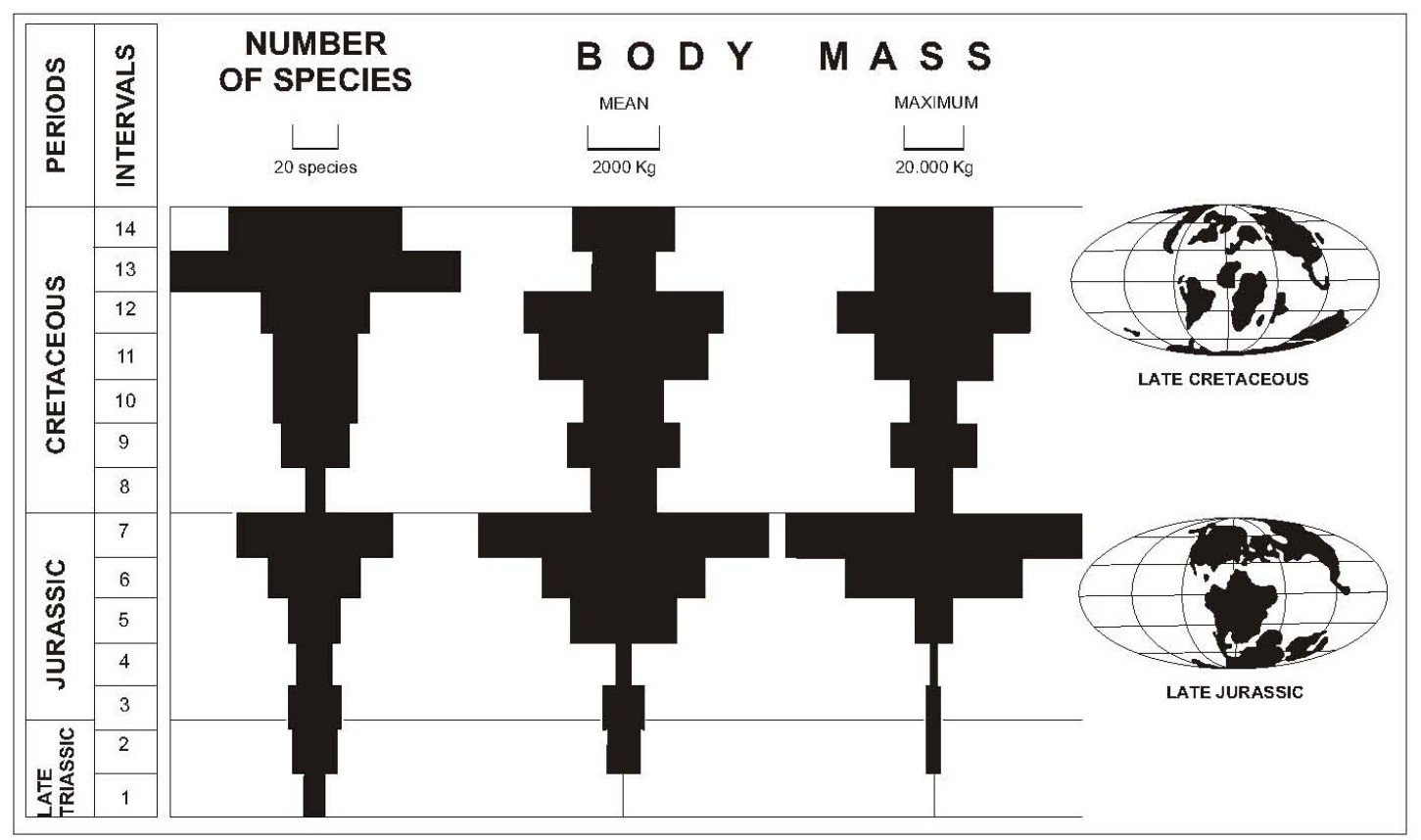

Figure 1. Species-level diversity and body size of dinosaurs over their history. Distribution of land masses on Earth in the Late Jurassic and in the Late Cretaceous after Smith et al. (1994) is also presented. For duration and geological age of the intervals consult Table 1. Further explanations and discussion in the text 